\title{
Rethinking Human Rights through the Language of Capabilities: An Introduction to Capabilities Approach
}

\author{
Latika Vashist*
}

\section{Abstract}

This paper seeks to contrast the language of human rights with capabilities approach conceptualized by Amartya Sen and Martha Nussbaum. While capabilities approach is an effective way of comprehending and implementing the rights guaranteed to people, language of human rights remains the essential pre-requisite for the development and enhancement of people's capabilities. While both these frameworks for justice operate within the western liberal paradigm, capabilities approach fills in the gaps of modern human rights discourse. The new idea of justice that accords a central place to human dignity mandates that the human rights entrenched in the Constitution be read as capabilities. The desperate vacuum that exists between the promises of law and realities of existence can only be bridged by institutionalizing a blend of rights and capabilities in the pursuit of justice. The paper argues that the language of human rights and that of capabilities ought to supplement and complement each other for true human flourishing.

Keywords: Capabilities, Human Rights, Judiciary, Justice, Liberty

\section{Introduction}

Amongst the diverse theories of justice that abound the philosophical space, capabilities approach is a unique idea striving

* Assistant Professor, Jindal Global Law School, O P Jindal Global University, Sonipat, Haryana. 
for justice. Novelty of this theory lies in the fact that it sees injustice in the form of inequalities in capabilities rather than income or resources. The method it suggests to address this injustice is through enhancement of people's capabilities (which is not restricted to the conventional re-distribution of income) so that they can lead a life which reflects true human flourishing.

Capability refers to the ability of people to be able to effectively do and be what they value in their lives. The paradigm of capabilities suggests one way of answering the critical question of the philosophical world - Equality of What? Though there is no disagreement as to "all human beings are born free and equal in dignity and rights" 1 inequality continues to stare back at us. Different equalitarian theories of justice demand equality in diverse spaces: John Rawls, for instance, argues for equality in the space of liberty and distribution of 'primary goods,'2 Ronald Dworkin in 'resources,'3 Robert Nozick argues for equality of libertarian rights (i.e. no one has more right to liberty than anyone else) ${ }^{4}$ and utilitarians in the space of everyone's weight for utility. ${ }^{5}$ Capabilities approach instead argues that the value of equality is most effective in the space of 'capabilities,' i.e. the freedom to be able to be or to do what one values.

Further, in contrast to the economic criterion of advancement- the GNP and the GDP- capabilities approach is a more authentic determinant of the actual condition of people. The economic

${ }^{1}$ United Nations Universal Declaration of Human Rights, G.A. res. 217A (III), U.N. Doc A/810 at 71 (1948), art. 1.

2 JOHN RAWLS, A THEORY OF JUSTICE (1971).

3 RONALD DWORKIN, TAKING RIGHTS SERIOUSLY (1978).

4 Robert NOZICK, ANARCHY, STATE AND UTOPIA (1974) (disputing the arguments made for equality of holdings of primary goods but Nozick too argues for equality of libertarian rights i.e. no one has more right to liberty than anyone else).

5 AMARTYA SEN, THE IDEA OF JUSTICE 292 (2009) (it is interesting to note the presence of a 'hidden' egalitarianism in utilitarian philosophy as there is an insistence on equal weights on everyone's utility gains in the utilitarian objective function). 
criteria of advancement or the quantitative national income estimation supplies a grossly incomplete account of human flourishing because it "concentrates on the means of living as the end-point of investigation." Nobel laureate Amartya Sen, while exploring his idea of justice tells us the inadequacy of these determinants:

"There are excellent reasons for not confusing means with ends, and for not seeing incomes and opulence as important in themselves, rather than valuing them conditionally for what they help people to achieve, including good and worthwhile lives." 6

No doubt economic opulence and substantive freedom are closely related but they very often tend to diverge. This is evident from the fact that the extent of deprivation and impoverishment inflicted upon many socially disadvantaged groups in the so-called developed countries is comparable to their developing counterparts. Thus, the real determinant is, and thus must be, what each person is actually able to do and be in his life. ${ }^{7}$ The capabilities approach, thus, focuses on choice and freedom, placing the individual in the centre, in contrast with the other philosophical approaches that concentrate on subjective variables like peoples' happiness or desire fulfillment, or the theoretical and practical approaches which have income, expenditures, consumption etc. as their focal point.

\section{Human Rights v. Human Capabilities}

Capabilities approach is seen as a species of the human rights approach. ${ }^{8}$ It is quite evident as the capabilities that are included in the list of central human capabilities carved out by Martha

${ }^{6} I d$. at 226 .

7 This understanding motivates the 'human development approach' which has shifted from the means-based perspective of GNP to focusing on human lives themselves. The UN Human Development Reports published since 1990 reflect the latter model of measuring development.

8 Martha C. Nussbaum, Frontiers OF JusticE: Disability, NATIONALITY, SPECIES MEMBERSHIP 284 (2006). 
Nussbaum $^{9}$ and the illustrations given by Amartya Sen, include many of the entitlements which are essentially stressed in the human rights movement, viz., political liberties, freedom of association, freedom to occupation and various economic and social rights. The goals of both the capabilities approach as well as human rights approach are essentially the same - shifting the focus from wealth of nations to the health of nations (in terms of a moral and humanist development), providing fundamental entitlements due to every human being that become the guiding star for constitutional thought within a nation and finally, paving way for international justice.

Despite these broad similarities, language of capabilities cannot be relegated to nothing but a playful use of new words that essentially convey the same meaning and have the same spirit. Capabilities, rather, supplement the language of rights to develop a conception of good which solely the human rights language could not do. Nussbaum has provided a lucid account of the differences in these two ethical languages the primary arguments of which are presented in the following paragraphs.

Capabilities approach transcends the dichotomy of 'modern conception of human rights'10 as "capabilities cover the terrain occupied by both the so-called first-generation rights (political and civil liberties) and the so-called second-generation rights (economic and social rights)." 11 The rights tradition of liberal political thought demarcates separate, independent and mutually exclusive spheres for political and civil liberties and social and economic rights. Rawlsian theory of justice being a part of this tradition gives lexical priority to liberty over economic principles and for societies at a lower stage of economic development, he holds that denial of liberty can be accepted "to enhance the quality of civilization so

${ }^{9} \mathrm{Id}$. at $76-78$.

${ }^{10}$ UPENDRA BAXI, THE FUTURE OF HUMAN RIGHTS 42 (2008) (establishing that the expression 'modern conception of human rights' is used in the light of the distinction between modern human rights and contemporary human rights made by Professor Upendra Baxi).

11 NUSSBAUM, supra note 8 at 284. 
that in due course the equal freedom can be enjoyed by all." 12 This understanding is premised on the anachronistic debate which places 'freedom' and 'bread' in conflicting, antagonistic zones and is suggestive of the misleading proposition that liberty is causally independent of economic distribution after a certain stage of development. ${ }^{13}$

Capabilities approach, in contrast, seeks to give human needs as much recognition as the human rights and hence, questions the fundamental basis of the traditional liberal thought. Recognizing the interdependence and inseparability of so called first-generation and second generation rights, its proponents argue that an adequate account of freedom of speech involves discussion of economic distribution (say, the distribution of education). Even if it can be argued that the two spheres are not interdependent, it cannot be denied that the freedom of speech and political freedom have material prerequisites, even in a developed society. People who are denied education are not able to exercise political speech in equality with the literate and educated. In Political Liberalism, Rawls also seems to shift from his earlier position and he acknowledges the interdependence of liberty on socio-economic factors. He concedes that the principle of equal basic liberties might be preceded by a principle requiring that citizen's basic needs be met "at least insofar as their being met is necessary for citizens to understand and to be able fruitfully to exercise those rights and liberties." 14 Capabilities approach with its focus on "what people are actually able to do and to be' gives equal weight to liberty (ability to do/ not do something) as well as economic arrangements (which ensure that people are actually able to function in accordance with their liberties granted to them).

Further, the language of capabilities gives 'precision' to the language of rights. There are wide philosophical disagreements in the understanding of rights. There are still wide range of ambiguities about questions like what is the basis of rights

\footnotetext{
12 RAWLS, supra note 2 at 542.

${ }^{13}$ UPENDRA BAXI, RigHT TO BE HUMAN 185-199 (1987).

14 JOHN RAWLS, POLITICAL LIBERALISM 7 (1993).
} 
(rationality, sentience or mere human life?), whether rights are prepolitical or artefacts of laws and institutions (just by virtue of we being 'human' or nothing but 'non-sense upon stilts'?), who are the subjects of rights (individuals or groups?) etc. Besides these, there are many other questions which add ambiguity to the rights discourse. For instance, what is the relationship between rights and duties? If $\mathrm{A}$ has a right to $\mathrm{X}$, then does that mean that someone has a duty to provide $\mathrm{X}$ ? If yes, then who is that someone? Moreover, there are also disagreements on the understanding of the expression right to. Is it right to resources with which one may accomplish her plans or right to opportunities with which one can make choices or right to a particular level of well being? Owing to these blurred areas in the rights discourse, the language of central capabilities has the advantage "of taking clear position on these disputed issues, while stating clearly what the motivating concerns are and what the goal is." 15 Further, the language of capabilities surpasses debates of cultural and historical antecedents of rights and thus, is more likely to be accepted universally.

However, considering that the 20 $0^{\text {th }}$ century has been the age of rights, it is not very easy to expect the world to free itself from the hegemony of the rights discourse. Thus, rather than endeavouring for a replacement of rights language, Nussbaum proposes that for rights to become more meaningful, they should instead be seen as capabilities. Thus, "to secure rights to citizens is to put them in a position of combined capability to function in that area." 16 This would work as a movement from rhetoric to reality. In the case of political participation, for example, the concern would be to adopt effective measures so that people become truly capable of exercising this right, like pre-election disclosure of the candidates credentials which enables the voters to make an informed choice; a nominal right of political participation on paper means little for the capabilities theorists.

15 Martha C. Nussbaum, Women and Human Development 97 (2000).

16 Id. at 98; see also Martha C. Nussbaum, Capabilities and Human Rights, 66 FORDHAM L. ReV. 273 (1997); Martha C. Nussbaum, Human Rights and Human Capabilities, 20 HARV. HuM. RTS. J. 21 (2007). 
Viewing rights in terms of capabilities is especially important in case of economic and material rights. The language of capabilities attaches clear meaning to them. Right to shelter, for example, can mean a lot of different things viewed from different perspective. ${ }^{17}$ Right to shelter could mean giving people certain amount of resources, it could mean securing people any shelter and measuring their satisfaction or it could mean looking at how people are actually enabled to live. Nussbaum argues that the third perspective to rights is the best way of analyzing rights, especially economic and material rights. ${ }^{18}$ Both resources-based and utilitybased analyses provide us with an incomplete picture as giving equal resources to differently situated people does not bring them to same level of capabilities to function. Similarly, utility cannot be an effective guide for determining if people enjoy equal rights; in a traditionally deprived society people may be easily satisfied with a standard of living which a rich person can't even conceive of in her dreams. Capabilities analysis "thus enables us to set forth clearly a rationale we have for spending unequal amounts of money on the disadvantaged, or creating special programs to assist their transition to full capability." 19

The public-private dichotomy that is inherently entrenched in the traditional liberal rights discourse is also bypassed by the capabilities approach. Though the struggle of feminist movements across the globe to uncover the myth of public-private has greatly transformed the human rights discourse,20 the dilemma still persists for most states. Attempts to extend the reach of human rights into the small kingdoms of family are met with stiff resistance as the fate of Article 16 of Convention on the Elimination

17 B.B. Pande, Re-Orienting the 'Rights' Discourse to Basic Human Needs, in HUMAN RIGHTS AND BASIC NEEDS: THEORY AND PRACTICE 168-169 (Mahendra P. Singh and ors. (eds.), 2008). (stating the rhetoric behind right to shelter in the Indian Apex Court decisions unveils the inadequacy and limitation of the rights language to be able to render complete justice).

18 NUSSBAUM, supra note 15 at 99.

${ }^{19} \mathrm{Id}$.

20 See generally Madhu Mehra, And miles to go...Challenges facing Women's Human rights, 40 JOURNAL OF INDIAN LAW INSTITUTE 123 (1998). 
of Discrimination Against Women, 1979 reveals. Article 16 seeks to eliminate discrimination in all matters relating to marriage and family relations. This Article has attracted most reservations from state parties. In Nussbaum's list of central human capabilities, the threshold level of each of which should be secured to each and every person, the ability to move freely from place to place and security against sexual assault (including domestic violence) figures quite predominantly which strikes the very root of the public-private divide. Issues like marital rape which remain legitimised in the rights jurisdictions will have no space to breath in the paradigm of capabilities which treats every human being as an end in herself, in both her public and private life.

In their zeal for the language of capabilities, the capabilities scholars have never suggested a complete supersession of the language of human rights. Primarily because rights are suggestive of justified and urgent claims that a person possesses and can rightfully claim against the mighty state. Capabilities, in contrast, still have a vagueness attached to them. Moreover, rights discourse is broadly the "terrain of agreement", unlike the relatively novel idea of capabilities. It is, thus, easier to address and resolve the conflicting and ambiguous areas of that discourse, than dumping it for an approach, no matter how radical, which still lacks a unanimous and consensual backing.

\section{Capabilities Approach and Judicial Interpretation}

The discourse of equality becomes meaningless if it fails to clearly explain the space which it seeks to address and where it demands equality. The judiciary which is entrusted with the task of interpreting and defining the contours of right to equality faces this question as much as the policy makers but it is the question "equality of what" is largely ignored by it. The judicial interpretation of right to equality continues to be guided by the common-sense produced by the liberal discourse (with an obsession with negative liberty) and fails to integrate the interest of other subjects of justice. The status quoist meaning of equality guides the judicial interpretation as is evident from the decisions which fail to contextualize equality. The most recent of such unwelcome judicial decisions is the order in which the Supreme Court denied 
permission to a dyslexic student to use calculator in his mathematics paper in the Class XII examinations conducted by the Central Board of Secondary Education as it was not in the Board's rule book. ${ }^{21}$ It is particularly important to note here that the form of power exercised by the judicial structure is not what works on people, it rather is what covertly works through them. It is the internalisation of the notion that differently abled people deserve sympathy/ charity and not rights that confers social legitimacy on such exclusionary orders. Interestingly in the aforementioned decision, the court chose to rely upon the formal notion of equality where everyone is treated equally in blatant disregard and ignorance of their peculiar circumstances and situations in life. This notion of equality (all students to be treated equally) ended up perpetuating inequality in reality.

There is no doubt that justice could have been done had the court resorted to the constitutional principle of 'likes to be alike,' but the application of the capabilities approach in the aforementioned case would have given an absolutely different perspective of the situation. The broader issue would have been of securing to the dyslexic student his right to be human by guaranteeing him facilities that enable him to live a fully human life in an otherwise disabled unfriendly physical and social environment. The judges should have asked themselves whether the dyslexic student would have equal opportunity to be able to do what he values (here mathematical calculations) as other non-dyslexic students? The answer would be certainly a 'no'. The court to ensure equality between the students should have permitted the use of calculator as that would have enabled the dyslexic student to overcome his disability. This may prima facie appear to be unequal (for the rules of the examination would have had to be changed for one person), but if equality is seen vis-à-vis capabilities, granting him permission was the only way to ensure real equality. The court instead was

21 Master Pranjay Jain (Minor) TR. Gaurdian v. U.O.I. \& Ors. (Supreme Court order available at http:// courtnic.nic.in/ supremecourt/ temp/ dc\%20852110p.txt) (stating that it is noteworthy that the I.C.S.E. board had been permitting students to use a calculator in the board examinations and the 2007 national policy of the Central government also had provisions for the students with disability to use the calculator). 
guided by the notion of equality in resources or equal rules for all students, which in effect perpetuated inequality.

The strength of the capabilities approach lies not only in the fact that it truly individualizes justice, but also because it values every human being as an end in herself. It humanizes the rights discourse by including the hitherto excluded, elevating their status from those who deserve charity to those who are claimants of equal rights. Capabilities approach calls for radical changes in the structures - physical as well as social - of society that are made according to the interests and for the convenience of the dominant groups. Thus, capabilities approach is a better paradigm that ensures equality and facilitates justice.

\section{Conclusion}

To summarise, it would be appropriate to say that the language of human rights and that of capabilities ought to supplement and complement each other for true human flourishing. While capabilities approach is an effective way of comprehending and implementing the rights guaranteed to people, the human rights discourse is the essential pre-requisite for the development and enhancement of people's capabilities. Thus, the new idea of justice that accords a central place to human dignity mandates that the human rights entrenched in the Constitution be read as capabilities. The onus is on the judiciary to evolve such principles of interpretation that the focus is always directed to the end result i.e. what a person is able to do or be through the claims and entitlements of rights. The desperate vacuum that exists between the promises of law and realities of existence can only be bridged by institutionalizing a blend of rights and capabilities in the pursuit of justice. 